Article

\title{
Comparison of Electrochemical Concentration Cell Ozonesonde and Microwave Limb Sounder Satellite Remote Sensing Ozone Profiles for the Center of the South Asian High
}

\author{
Chunhua Shi * (1), Chenxin Zhang and Dong Guo \\ Key Laboratory of Meteorological Disaster, Ministry of Education (KLME)/Joint International Research \\ Laboratory of Climate and Environment Change (ILCEC)/Collaborative Innovation Center on Forecast and \\ Evaluation of Meteorological Disasters, Nanjing University of Information Science and Technology, \\ Nanjing 210044, China; 20161201097@nuist.edu.cn (C.Z.); dongguo@nuist.edu.cn (D.G.) \\ * Correspondence: shi@nuist.edu.cn; Tel.: +86-132-180-58678
}

Received: 1 August 2017; Accepted: 23 September 2017; Published: 29 September 2017

\begin{abstract}
To further verify the ozone profile reliability of satellite remote sensing for the ozone valley over the Tibetan Plateau in the core area of the South Asian high in summer, we validate the ozone products from the microwave limb sounder (MLS) onboard the Aura satellite over the Tibetan plateau using electrochemical concentration cell (ECC) ozonesonde data of 2016 for Ngari, Tibet. The MLS version four ozone profiles have lower standard deviation in the middle stratosphere (38-10 hPa), whereas the ozonesonde profiles have lower standard deviation in the upper troposphere and lower stratosphere region (200-83 hPa). There are statistically significant differences between these two datasets in most of the stratosphere $(10-83 \mathrm{hPa})$. The mean value of MLS ozone is about $0.8-1.5 \mathrm{mPa}$ greater than that of ECC ozone, which corresponds to a relative deviation of $59 \pm 24 \%$ at $83 \mathrm{hPa}$, $24 \pm 13 \%$ at $68 \mathrm{hPa}, 20 \pm 5 \%$ at $56 \mathrm{hPa}, 14 \pm 4 \%$ at $46 \mathrm{hPa}$ and $38 \mathrm{hPa}$, and $9 \pm 4 \%$ in the layers between 32 and $10 \mathrm{hPa}$. However, there is no statistically significant difference between the two datasets in the upper troposphere $(100-200 \mathrm{hPa})$.
\end{abstract}

Keywords: ozone profile; ozonesonde; MLS; validation; South Asian high

\section{Introduction}

The stratospheric ozone layer absorbs solar ultraviolet radiation and then heats the atmosphere. This has an important impact on the dynamical and thermodynamic structure of the stratosphere. The distribution of ozone affects the stratosphere-troposphere exchange near the tropopause and is controlled by large-scale circulation. There is a large depression in total column ozone of $\sim 30$ DU relative to the surrounding area (sometimes referred to as an 'ozone valley') in the upper troposphere and lower stratosphere (UTLS) region over the Tibetan Plateau [1-6], which is under the influence of the South Asian high in summer. At present, most ozone profile data are derived from satellite remote sensing instruments; for example, the Halogen Occultation Experiment (HALOE) [7], the Stratospheric Aerosol and Gas Experiment (SAGE) [8], and the microwave limb sounder (MLS) [9]. The remote-sensing algorithm used for ozone profiles shows little difference in zonal distribution, but the actual local dynamic and thermal structures vary widely, resulting in a large deviation in ozone profiles in certain locations. Therefore, it is important to compare satellite remote sensing-derived ozone profiles with ozonesonde data and correct the profiles in key areas such as the Tibetan Plateau.

Satellite remote sensing products may be validated with independent measurements. For example, the ozone products of MLS are consistent with ozonesonde data at 150-3 hPa, and the global average 
error is less than $8 \%$ [10]. The average deviations of the total tropospheric ozone between Global Ozone Monitoring Experiment (GOME) satellite products and ozonesonde products are within 10\% [11]. Total Ozone Mapping Spectrometer (TOMS) retrieved value is lower than ground-based measurements in China [12]. MLS v4 ozone offers benefits relative to MLS v3 ozone by comparing with ozonesonde data over the Tibetan Plateau [13]. The South Asian high (Asian summer monsoon anticyclone) is a very strong circulation in the UTLS region over the Tibetan Plateau. The nearby stratospheric tracers such as ozone are greatly influenced by locations relative to South Asian high and the variation of South Asian high [1-4].

In previous studies, comparisons between ozonesonde measurements and satellite remote sensing ozone profiles for the ozone valley over the Tibetan Plateau have been mostly carried out near Lhasa, Nagqu, Kunming, and Tengchong [13-16], which are mostly located in the east of the South Asian high region (Figure 1). Ozonesonde data from the central region of the South Asian high are rare due to alpine hypoxia, bad weather, and poor traffic. However, we have obtained ozone data for summer 2016 from the balloon-borne ozonesonde at Shiquan River in Ngari, which is located in the central region of the South Asian high, providing an opportunity to validate MLS ozone version 4.2 products with ozonesonde data in this region. This study will provide a further reference for the application of satellite ozone products in the ozone valley over the Tibetan Plateau in summer.

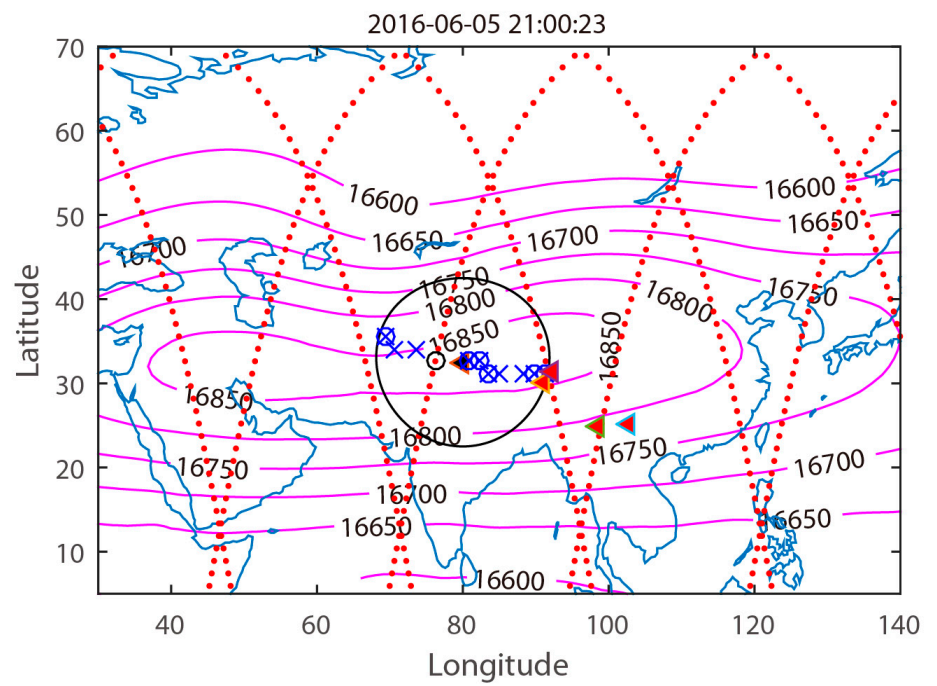

Figure 1. Trajectory distribution of MLS ozone profiles at $50 \mathrm{hPa}$ on 5 June 2016 (red solid dots); the position of the nearest matching MLS profile (black hollow circle) to the Shiquan River ozonesonde station (black triangle); the remaining 16 matching MLS ozone profiles (blue crosses or hollow circles); the maximum matching distance (large black circle); and locations of the other ozonesonde stations (red triangles for Lhasa, Nagqu, Tengchong, and Kunming). The geopotential height (pink contours; m) in July and August 2016 is from the ERA-Interim dataset.

\section{Materials and Methods}

\subsection{Ozonesonde Data}

Electrochemical concentration cell (ECC) ozonesondes are balloon-borne instruments which can make in situ measurements of ozone profile [17]. The vertical resolution of ozone is decided by ECC response time and balloon ascent rate. The typical vertical resolution is about 100-150 m [18]. ECC measurements are typically accurate to within $10 \%$ in the troposphere and 5\% in the stratosphere up to $10 \mathrm{hPa}$ [19]. ECC ozone sounding was performed at Shiquan River, Ngari, in Tibet $\left(32.5^{\circ} \mathrm{N}, 80^{\circ} \mathrm{E}\right)$ for this study. The site is located in the core area of the Qiangtang Plateau, and is also close to the central region of the South Asian high. These observations are suitable for validating the ozone profiles derived from MLS satellite remote sensing data for the ozone valley over the Tibetan Plateau in summer. The detecting 
instrument used is the Finland Vaisala ECC ozonesonde, which is based on the relationship between ozone concentration and the intensity of the electrochemical signals generated by an electrochemical reaction between ozone and nonsaturated potassium iodide in the reaction tank [20]. The sounding balloon usually bursts by itself near an altitude of $30 \mathrm{~km}$. The ECC ozonesonde measures the ozone profile during the ascent of the sounding balloon. The balloons were normally launched around midnight local time from June to September 2016. The exact dates of the 17 valid ozone profiles are 5 June, 16 June, 22 June, 25 June, 1 July, 4 July, 10 July, 13 July, 18 July, 21 July, 31 July, 25 August, 28 August, 3 September, 6 September, 12 September, and 21 September.

\subsection{MLS Ozone Products}

The MLS is an instrument onboard the Earth Observing System's Aura satellite, which was launched by NASA of the United States in July 2004. The MLS measures the atmospheric composition, temperature, humidity, and cloud ice. The data quality of the MLS Level 2 Version 4 ozone products is greatly improved compared to the MLS version 3 ozone products for the UTLS region [21]. The comparisons between MLS v4 ozone and ECC ozonesonde were carried out [13,22]. The MLS v4 ozone profiles used in this study are filtered by the quality control criteria [21].

\subsection{ERA-Interim Dataset}

The European Center for Medium-Range Weather Forecasts interim reanalysis (ERA-Interim) global monthly dataset is used in this study [23]. The online service is at https:/ / www.ecmwf.int/en/ research/climate-reanalysis/era-interim.

\subsection{Methods}

To analyze the two datasets, it is first necessary to make them comparable, since they differ both in vertical resolution and the horizontal location of the ozone profiles. The MLS ozone profile nearest to the ozonesonde station in terms of horizontal distance is selected as a matching profile. The sounding time is around midnight local time, which has an offset of less than three hours relative to the nearest MLS profile in the descending orbit. Figure 1 shows the location of the matched profile on 5 June 2016 and the positions of the other 16 matching profiles. The selected profile usually has a distance within $10^{\circ}$ longitude and $3^{\circ}$ latitude from the ozonesonde station. The zonal distribution of stratospheric ozone is relatively uniform, so the error for this matching is small.

The vertical resolution of the MLS ozone profile is much lower than that of the ozonesonde profile. To compare the two ozone datasets at the same pressure, the ozonesonde profiles are interpolated into 16 layers of the MLS ozone between 10 and $200 \mathrm{hPa}$ in log-pressure. This handling is useful for not only converting the different ozonesonde profiles to the same isobaric surface, but also comparing ozonesonde and MLS ozone profiles at the same 16 barometric layers. All the data are combined (all the days) in the figures and table. The MLS ozone unit is converted into ozone partial pressure $(\mathrm{mPa})$ as that for ECC ozonesondes. Several statistical equations are used as follows:

$$
\begin{gathered}
\sigma=\sqrt{\frac{1}{N} \sum_{i=1}^{N}\left(x_{i}-\mu\right)^{2}} \\
b_{i}=\frac{\sum_{k=1}^{N}\left[x_{m l s}(k)-x_{\text {sonde }}(k)\right]}{N} \\
\sigma_{b}=\sqrt{\frac{\sum_{k=1}^{N}\left[x_{m l s}(k)-x_{\text {sonde }}(k)-b_{i}\right]^{2}}{N(N-1)}}
\end{gathered}
$$

Equation (1) is the standard deviation of a variable, also known as the mean square error or the variance of the arithmetic square root, where $x i$ denotes the ozone value at a specific pressure, the subscript $i$ indicates the different profiles, and $\mu$ is the average value of $x i$. The standard deviation 
can illustrate the discretization degree and the variation in an ozone dataset here. Equation (2) is the average deviation at a certain pressure between the MLS and ozonesonde data. Equation (3) is the standard error of Equation (2), which represents the distribution of the mean deviation, and it is obtained from the covariance matrix of the sample [24,25]. Equations (2) and (3) can be used to compare the difference between two ozone datasets. The difference is statistically significant when the standard error bar does not cover zero. The average deviation and the standard error can be normalized by the mean of ozonesonde data (assumed to be true value) in relative deviation analysis.

\section{Results}

\subsection{Comparison of Ozone Profiles between the Two Datasets}

The two ozone datasets differ more significantly in the stratosphere than in the troposphere for the Tibetian plateau and the summer season. Figure 2 shows that a minimum ozone concentration of less than $2 \mathrm{mPa}$ is located near the tropopause (about 100 to $150 \mathrm{hPa}$ ) in both profiles. The concentration increases with height in the stratosphere until it reaches a maximum value of greater than $12 \mathrm{mPa}$ near $25 \mathrm{hPa}$, and then it decreases with height. The MLS ozone profiles have lower standard deviation in the middle stratosphere (38-10 hPa), while the ozonesonde profiles have lower standard deviation in the UTLS region $(200-83 \mathrm{hPa})$.
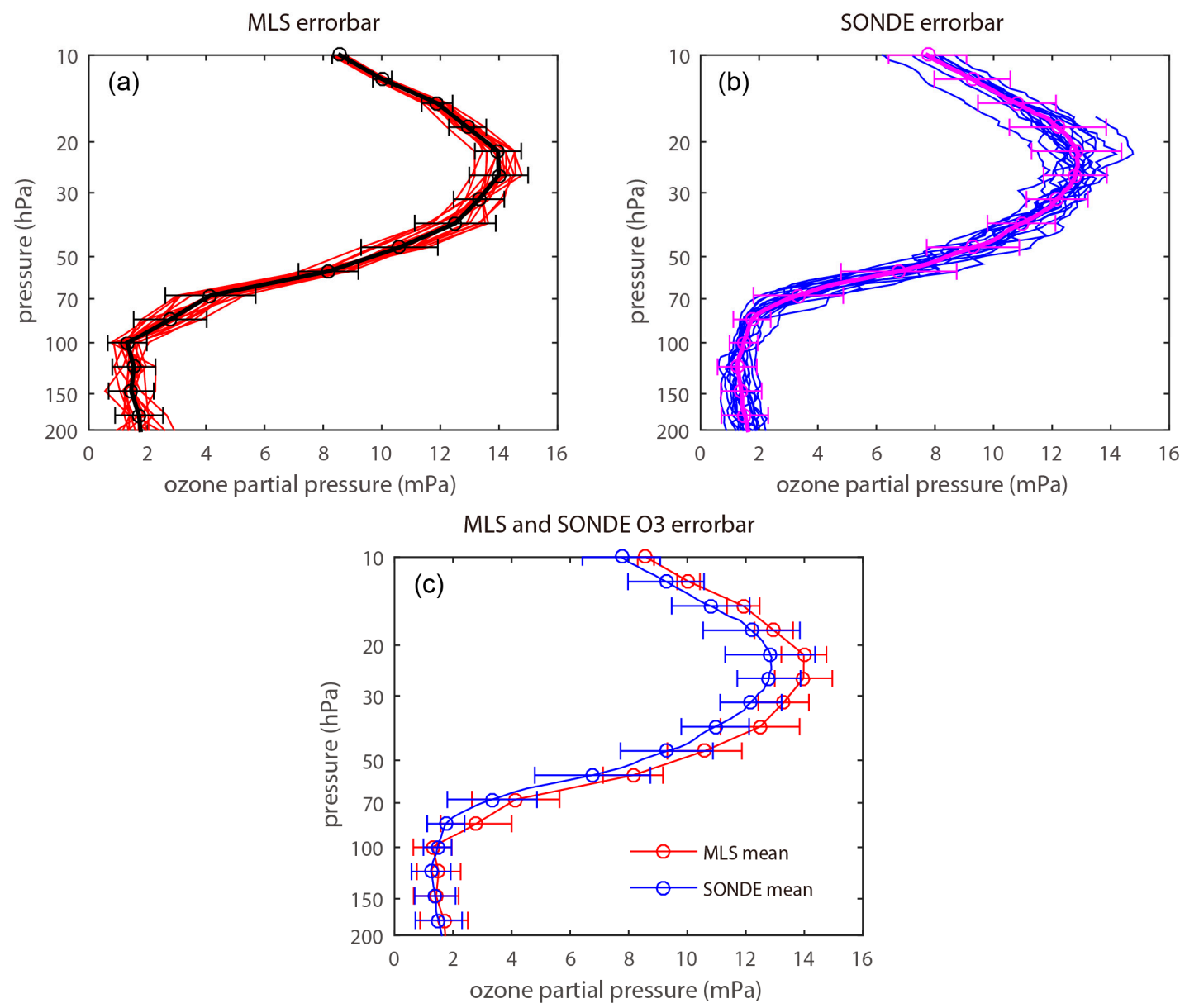

Figure 2. (a) Ozone profiles (red) and the mean profile with \pm 2 standard deviation (black) derived from MLS data. (b) As in (a), but derived from ozonesonde data. (c) Mean ozone profiles with \pm 2 standard deviation for MLS (red) and ozonesonde (blue). 
The mean deviation of the two datasets and their reliability are shown in Figure 3 . The average deviation and standard error are determined from Equations (2) and (3). At 100-200 hPa, there is no statistically significant difference between the two datasets, which is illustrated by the small average deviation (less than $0.3 \mathrm{mPa}$ ) with its \pm 2 standard error covering zero. The possible reasons are the small mean deviation of the two datasets and the large standard deviation of the MLS ozone in the UTLS region (also shown in Figure 2c). At $10-83 \mathrm{hPa}$, the standard error is smaller but the mean deviation is greater between the MLS and ozonesonde data, which illustrates that the difference is statistically significant. The ozone concentration derived from the MLS data is $0.8-1.5 \mathrm{mPa}$ greater than that derived from the ozonesonde data (Figure 3a). The relative deviation of the MLS data relative to the ozonesonde data is $59 \pm 24 \%$ at $83 \mathrm{hPa}, 24 \pm 13 \%$ at $68 \mathrm{hPa}, 20 \pm 5 \%$ at $56 \mathrm{hPa}, 14 \pm 4 \%$ at $46 \mathrm{hPa}$ and $38 \mathrm{hPa}$, and $9 \pm 4 \%$ in the layers between 32 and $10 \mathrm{hPa}$ (Figure $3 \mathrm{~b}$ ). The relative deviation of MLS relative to ozonesonde over Shiquan River in the central region of the South Asian high is larger than the global MLS deviation [10] but less than that in Lhasa, Tengchong, and Naqu [13], which are located in the east of the South Asian high center.
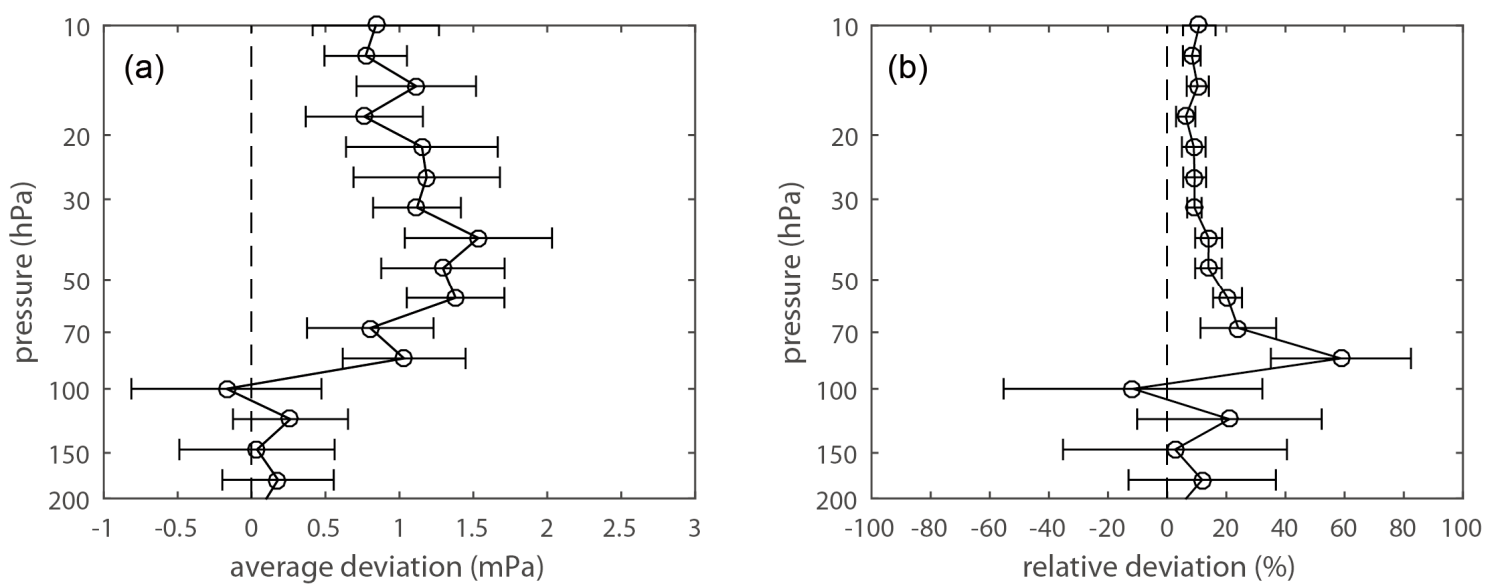

Figure 3. (a) Average deviation of MLS ozone profile relative to the ozonesonde profile with \pm 2 standard error. (b) As in (a), but for relative deviation.

\subsection{Linear Regression Analysis between MLS and Ozonesonde Data}

In the previous section, the data differences discussed are mainly based on the vertical distributions. The greater mean difference and smaller standard error in the stratosphere (Figure 3b) illustrate that the difference is statistically significant. As we know, MLS stratospheric ozone is more reliable than that in upper troposphere. However, the 'true' ECC ozonesonde data do have errors [19]. Therefore, the mean differences between the two ozone datasets could only be explained partly in the previous section. It is necessary to analyze the linear regression relationship between MLS and ozonesonde data in different layers.

Table 1 shows the linear fitting coefficients for the two ozone datasets at different pressure layers. For linear regression, ECC ozonesonde is an independent variable (we assume the ECC ozonesonde data represent true value here) and MLS ozone is a dependent variable. The slope $\beta$ represents the regression coefficient and $\alpha$ is the intercept (which reflects the system deviation of the MLS data). There are four pressure levels (marked with shaded background) where the regression passes the significance test at the 0.05 level (using Student's $t$-test). The linear regression diagrams for these four pressure levels are shown in Figure 4. The regression equation is $O_{3 M L S}=(0.63 \pm 0.50) \times \mathrm{O}_{3 \text { sonde }}+(0.55 \mp 0.71)$ in the upper troposphere $(147 \mathrm{hPa})$. In the lower and middle stratosphere $(68,56$, and $38 \mathrm{hPa})$, the regression equations are $O_{3 M L S}=(0.73 \pm 0.35) \times O_{3 s o n d e}+(1.69 \mp 1.21), O_{3 M L S}=(0.37 \pm 0.20) \times O_{3 s o n d e}+(5.65 \mp 1.37)$ and $\mathrm{O}_{3 M L S}=(0.63 \pm 0.54) \times \mathrm{O}_{3 \text { sonde }}+(5.60 \mp 5.92)$, respectively. The relative intercept of $\alpha / \bar{O}_{3 \text { sonde }}$ at 
$147,68,56$, and $38 \mathrm{hPa}$ is $40 \pm 51 \%, 51 \pm 36 \%, 83 \pm 20 \%, 51 \pm 54 \%$, respectively. In the upper troposphere, the regressions for most layers do not pass the significance test, mainly due to the large dispersion of the MLS data. Above $30 \mathrm{hPa}$, the regression correlation between the two datasets is not statistically significant; mainly due to the fact that the ozonesonde data has the largest standard deviation in Figure 2b. However, in the lower and middle stratosphere, the regression equations at the other two pressure levels of 83 and $46 \mathrm{hPa}$ pass the significance test at the 0.15 level. Therefore, in most of the lower and middle stratosphere, the slopes are slightly less compared with the three stations in the east of the South Asian high [14], while the relative intercepts of $\alpha / \bar{O}_{3 \text { sonde }}$ are generally greater, indicating a larger system deviation of MLS data at Shiquan River in the center of the South Asian high.
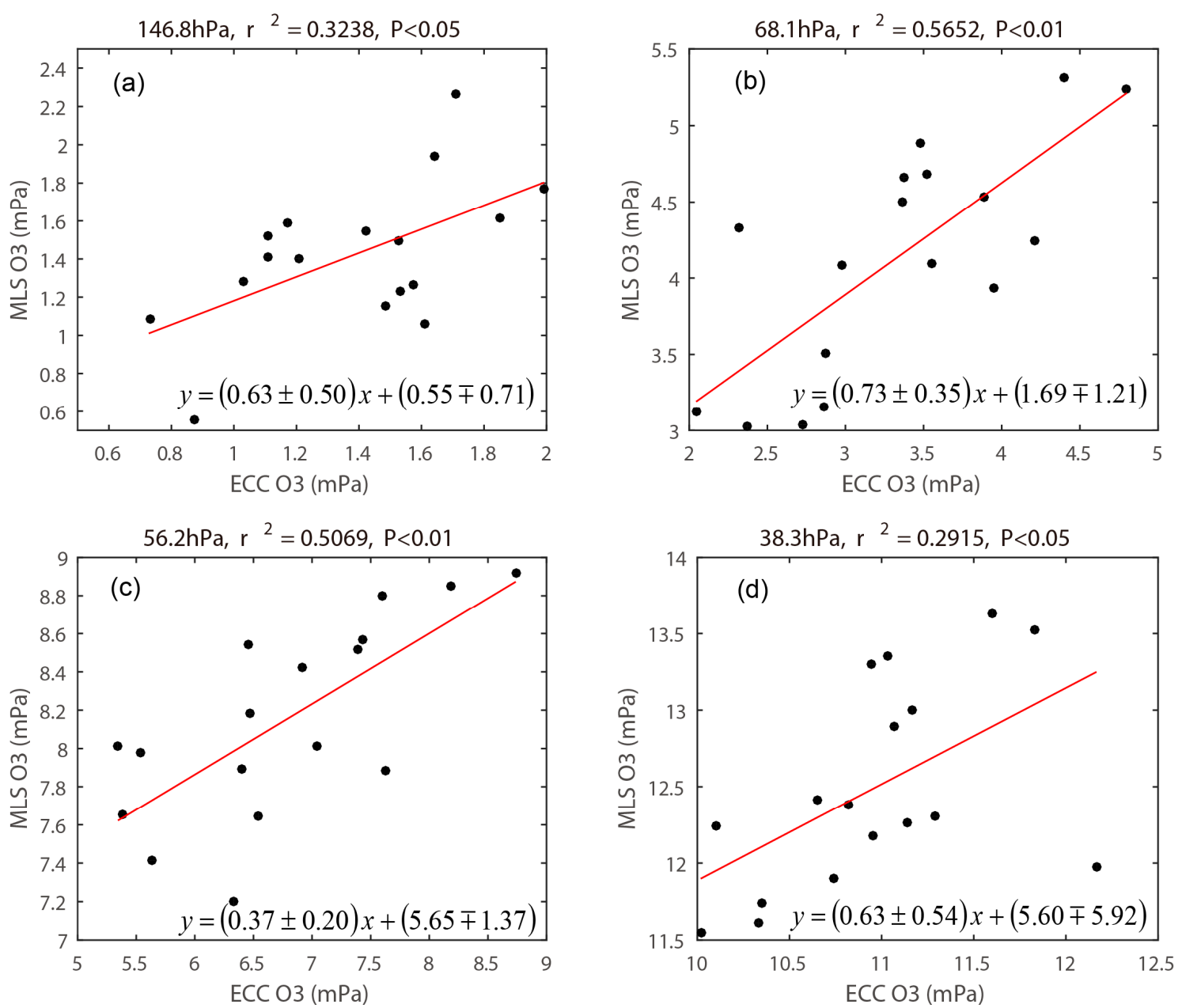

Figure 4. Linear regression relationship between MLS and ozonesonde data in the different layers: (a) $146.8 \mathrm{hPa}$; (b) $68.1 \mathrm{hPa}$; (c) $56.2 \mathrm{hPa}$; (d) $38.3 \mathrm{hPa}$. The interval estimate of the regression coefficient is given according to the $5 \%$ significance level. 
Table 1. Linear regression coefficients of MLS ozone and ozonesonde.

\begin{tabular}{|c|c|c|c|c|c|c|}
\hline Pressure (hPa) & $\begin{array}{c}\text { Coefficient of } \\
\text { Determination }\left(r^{2}\right)\end{array}$ & Slope $(\beta)$ & Intercept $(\alpha)$ & $\begin{array}{c}\alpha / \bar{O}_{3 \text { sonde }} \\
(\%)\end{array}$ & $\begin{array}{c}\bar{O}_{3 \text { sonde }} \\
(\mathrm{mPa})\end{array}$ & Probability (p) \\
\hline 215.4 & 0.03 & 0.43 & 1.04 & 61 & 1.7128 & 0.5186 \\
\hline 146.8 & 0.32 & 0.63 & 0.55 & 40 & 1.3869 & 0.0171 \\
\hline 121.2 & 0.10 & 0.34 & 1.08 & 87 & 1.2475 & 0.2285 \\
\hline 100.0 & 0.01 & -0.09 & 1.44 & 98 & 1.4687 & 0.7923 \\
\hline 68.1 & 0.57 & 0.73 & 1.69 & 51 & 3.3368 & 0.0005 \\
\hline 56.2 & 0.51 & 0.37 & 5.65 & 83 & 6.7669 & 0.0013 \\
\hline 46.4 & 0.16 & 0.32 & 7.58 & 82 & 9.2981 & 0.1102 \\
\hline 38.3 & 0.29 & 0.63 & 5.60 & 51 & 10.9522 & 0.0253 \\
\hline 31.6 & 0.10 & 0.27 & 10.06 & 83 & 12.1725 & 0.2070 \\
\hline 26.1 & 0.01 & -0.10 & 15.21 & 119 & 12.7878 & 0.6855 \\
\hline 12.1 & 0.01 & -0.01 & 10.05 & 108 & 9.2744 & 0.9840 \\
\hline
\end{tabular}

\section{Discussion}

Previous studies have shown that the global average difference between MLS ozone and ozonesonde data is less than $8 \%$ in most parts of the stratosphere [10]. However, the relative deviation of the MLS ozone over the Tibetan plateau is larger in this study. Nevertheless, in the lower stratosphere (especially at 83,68 , and $56 \mathrm{hPa}$ ), the relative difference between MLS ozone and ozonesonde over Shiquan River in the central region of the South Asian high is less than that [13] over Lhasa, Tengchong, and Naqu, which are located in the east of the South Asian high center. That may be attributed to the steady situations in the central region and the mutable conditions in the east location during the east-west oscillation (eastward-westward migration) of the Asian Summer Monsoon Anticyclone (the South Asian high) [26]. According to the linear regression relationship between MLS and ozonesonde data, in most of the lower and middle stratosphere, the slopes are slightly less compared with the three stations in the east of the South Asian high [14], while the relative intercepts of $\alpha / \bar{O}_{3 s o n d e}$ are generally greater, which also indicates a larger system deviation of MLS at Shiquan River in the center of the South Asian high.

The possible reasons for this result are as follows: (1) The ozonesonde station is located in the center of the summer South Asian high, where the ozone valley is deeper than that in the surrounding area. (2) The ozonesonde samples in this study are not sufficient and the conclusions may not be universal. (3) There are some limitations and errors associated with the spatial and temporal matching between the two datasets.

\section{Conclusions}

The present study validates Aura MLS version 4.2 ozone products using ECC ozonesonde observations over Shiquan River, Ngari in the center of the South Asian high region in summer of 2016. The MLS ozone profiles have lower standard deviation in the middle stratosphere (38 to $10 \mathrm{hPa}$ ), while the ozonesonde profiles have lower standard deviation in the UTLS region (200-83 hPa). There are statistically significant differences between the two datasets in most of the stratosphere $(10-83 \mathrm{hPa})$. The mean value of the MLS ozone is about $0.8-1.5 \mathrm{mPa}$ greater than that of ECC ozone, which corresponds to a relative deviation of $59 \pm 24 \%$ at $83 \mathrm{hPa}, 24 \pm 13 \%$ at $68 \mathrm{hPa}, 20 \pm 5 \%$ at $56 \mathrm{hPa}$, $14 \pm 4 \%$ at $46 \mathrm{hPa}$ and $38 \mathrm{hPa}$, and $9 \pm 4 \%$ in the layers between 32 and $10 \mathrm{hPa}$. However, there is no statistically significant difference between these two datasets in the upper troposphere (100-200 hPa). 
Acknowledgments: This study was jointly supported by National Science Foundation of China (91537213, 41375047 and 41675039), and Priority Academic Program Development of Jiangsu Higher Education Institutions (PAPD). We thank Xiangdong Zheng from Chinese Academy of Meteorological Sciences for providing the ozone sonde profiles. We also thank Jian Li, Lei Zhang, and Wenyi He from Chengdu University of Information Technology and Jiaren Yan from Nanjing University of Information Science and Technology for their in situ observations. We are thankful to Yong Zhang and Yonghong Ma from Meteorological Bureau of Tibet Autonomous Region for their assistance in observations. The provisions of online data by NASA and ECMWF are gratefully acknowledged.

Author Contributions: Chunhua Shi initiated and coordinated this work. Chunhua Shi and Chenxin Zhang provided the calculation and analysis. Chunhua Shi, Chenxin Zhang, and Dong Guo wrote the manuscript.

Conflicts of Interest: The authors declare no conflict of interest.

\section{References}

1. Bian, J.C.; Yan, R.C.; Chen, H.B.; Lu, D.R.; Massie, S.T. Formation of the summertime ozone valley over the Tibetan Plateau: The Asian summer monsoon and air column variations. Adv. Atmos. Sci. 2011, 28, 1318-1325. [CrossRef]

2. Guo, D.; Wang, P.X.; Zhou, X.J.; Liu, Y.; Li, W.L. The dynamic effects of the South Asian high on the ozone valley over the Tibetan Plateau. Acta Meteorol. Sin. 2012, 26, 216-228. [CrossRef]

3. Guo, D.; Su, Y.C.; Shi, C.H.; Xu, J.J.; Alfred, M.P., Jr. Double Core of Ozone Valley over the Tibetan Plateau and its Possible Mechanisms. J. Atmos. Terr. Phys. 2015, 130-131, 127-131. [CrossRef]

4. Guo, D.; Su, Y.C.; Zhou, X.J.; Xu, J.J.; Shi, C.H.; Liu, Y.; Li, W.L.; Li, Z.K. Evaluation of Trend Uncertainty of Summer Ozone Valley over Tibetan Plateau in Three Reanalysis Datasets. J. Meteorol. Res. 2017, 31, 431-437. [CrossRef]

5. Li, Z.K.; Qin, H.; Guo, D.; Zhou, S.W.; Huang, Y.; Su, Y.C.; Wang, L.W.; Sun, Y. Impact of Ozone Valley over the Tibetan on South Asian High in CAM5. Adv. Meteorol. 2017. [CrossRef]

6. Zhou, X.; Luo, C.; Li, W.L.; Shi, J.E. Variation of Total Ozone in China and Low-Value Center of Qinghai-Tibet Plateau. Sci. Bull. 1995, 40, 1396-1398.

7. Russell, J.M., III; Gordley, L.L.; Park, J.H.; Drayson, S.R.; Hesketh, W.D.; Cicerone, R.J.; Tuck, A.F.; Frederick, J.E.; Harries, J.E.; Crutzen, P.J. The Halogen Occultation Experiment. J. Geophys. Res. Atmos. 1993, 98, 10777-10797. [CrossRef]

8. Mauldin, L.E.; Zaun, N.H.; McCormick, M.P.; Guy, J.H.; Vaughn, W.R. Stratospheric Aerosol and Gas Experiment II Instrument: A Functional Description. Opt. Eng. 1985, 24, 242307. [CrossRef]

9. Waters, J.W.; Froidevaux, L.; Harwood, R.S.; Jarnot, R.F.; Pickett, H.M. The Earth observing system microwave limb sounder (EOS MLS) on the aura Satellite. IEEE Trans. Geosci. Remote. Sens. 2006, 44, 1075-1092. [CrossRef]

10. Jiang, Y.B.; Froidevaux, L.; Lambert, A.; Licesey, N.J.; Read, W.G.; Waters, J.W.; Bojkov, B.; Leblanc, T.; McDermid, I.S.; Godin-Beekmann, S.; et al. Validation of Aura Microwave Limb Sounder ozone by ozonesonde and lidar measurements. J. Geophys. Res. 2007, 112, 6033-6044. [CrossRef]

11. Cai, Z.N.; Wang, Y.; Liu, X.; Zheng, X.D.; Chance, K.; Liu, Y. Validation of GOME ozone profiles and tropospheric column ozone with ozone sonde over China. J. Appl. Meteorol. Sci. 2009, 20, 337-345. (In Chinese)

12. Pan, L.; Niu, S.J. A Comparison of Total Column Ozone Values Derived from AIRS, TOVS and TOMS. J. Remote. Sens. 2008, 12, 54-63.

13. Yan, X.L.; Wright, J.S.; Zheng, X.D.; Livesey, N.J.; Vömel, H.; Zhou, X.J. Validation of Aura MLS retrievals of temperature, water vapour and ozone in the upper troposphere and lower-middle stratosphere over the Tibetan Plateau during boreal summer. Atmos. Meas. Tech. 2016, 9, 3547-3566. [CrossRef]

14. Yan, X.L.; Zheng, X.D.; Zhou, X.J.; Vömel, H.; Song, J.Y.; Li, W.; Ma, Y.H.; Zhang, Y. Validation of Aura Microwave Limb Sounder water vapor and ozone profiles over the Tibetan Plateau and its adjacent region during boreal summer. Sci. China Earth Sci. 2015, 58, 589-603. [CrossRef]

15. Bian, J.C.; Pan, L.L.; Paulik, L.; Vömel, H.; Chen, H.B.; Lu, D. In situ water vapor and ozone measurements in Lhasa and Kunming during the Asian summer monsoon. Geophys. Res. Lett. 2012, 39, L19808. [CrossRef]

16. Zhen, X.D.; Tang, J.; Li, W.L.; Zhou, X.J.; Shi, G.Y. Observational study on total ozone amout and its vertical profile over lhasa in the summer of 1998. Q. J. Appl. Meteorol. 2000, 11, 173-179. (In Chinese) 
17. Vetter, K.J. Electrochemical Kinetics-Theoretical and Experimental Aspects; Translated by Academic Press Inc.; Originally Published as "Electrochemische Kinetik"; Springer: Heidelberg/Berlin, Germany, 1967.

18. Komhyr, W.D. Electrochemical concentration cells for gas analysis. Ann. Geophys. 1969, 25, $203-210$.

19. Smit, H.G.J.; Straeter, W.; Johnson, B.J.; Oltmans, S.J.; Davies, J.; Tarasick, D.W.; Hoegger, B.; Stubi, R.; Schmidlin, F.J.; Northam, T.; et al. Assessment of the performance of ECC-ozonesondes under quasi-flight conditions in the environmental simulation chamber: Insights from the Jülich Ozone Sonde Intercomparison Experiment (JOSIE). J. Geophys. Res. 2007, 112, D19306. [CrossRef]

20. Komhyr, W.D.; Barnes, R.A.; Brothers, G.B.; Lathrop, J.A.; Opperman, D.P. Electrochemical concentration cell ozonesonde performance evaluation during STOIC 1989. J. Geophys. Res. 1995, 100, 9231-9244. [CrossRef]

21. Livesey, N.J.; Read, W.G.; Wagner, P.A.; Froidevaux, L.; Lambert, A.; Manney, G.L.; Millán-Valle, L.F.; Pumphrey, H.C.; Santee, M.L.; Schwartz, M.J.; et al. Version 4.2x Level 2 Data Quality and Description Document; version 4.2x-1.0; Tech. Rep. JPL D-33509; NASA Jet Propulsion Laboratory: Pasadena, CA, USA, 2015.

22. Witte, J.C.; Anne, M.; Thompson, A.M.; Smit, H.G.J.; Fujiwara, M.; Posny, F.; Coetzee, G.J.R.; Northam, E.T.; Johnson, B.J.; Sterling, C.W.; et al. First reprocessing of Southern Hemisphere ADditional OZonesondes (SHADOZ) profile records (1998-2015): 1. Methodology and evaluation. J. Geophys. Res. Atmos. 2017, 122, 6611-6636. [CrossRef]

23. Dee, D.P.; Uppala, S.M.; Simmons, A.J.; Berrisford, P.; Poli, P.; Kobayashi, S.; Andrae, U.; Balmaseda, M.A.; Balsamo, G.; Bauer, P.; et al. The ERA-Interim reanalysis: Configuration and performance of the data assimilation system. Q. J. R. Meteorol. Soc. 2011, 137, 553-597. [CrossRef]

24. Rodgers, C.D. Characterization and error analysis of profiles retrieved from remote sonde measurements. J. Geophys. Res. 1990, 95, 5587-5595. [CrossRef]

25. Von Clarmann, T. Validation of remotely sensed profiles of atmospheric state variables: Strategies and terminology. Atmos. Chem. Phys. 2006, 6, 4311-4320. [CrossRef]

26. Luo, J.L.; Song, J.Y.; Tian, H.Y.; Liu, L.; Liang, X.L. A Case Study of Mass Transport during the East-west Oscillation of the Asian Summer Monsoon Anticyclone. Adv. Meteorol. 2017, in press.

(C) 2017 by the authors. Licensee MDPI, Basel, Switzerland. This article is an open access article distributed under the terms and conditions of the Creative Commons Attribution (CC BY) license (http:/ / creativecommons.org/licenses/by/4.0/). 